\title{
LEARNING SUSTAINABILITY IN THE HARVESTING PRACTICES OF A FOREST-BASED COMPANY ${ }^{1}$
}

\author{
KÁTIA CYRLENE DE ARAUJO VASCONCELOS ${ }^{2}$ \\ (iD) http://orcid.org/0000-0001-6972-7599 \\ ANNOR DA SILVA JUNIOR ${ }^{2}$ \\ http://orcid.org/0000-0003-4124-5277
}

To cite this paper: Vasconcelos, K. C. A., \& Silva, A. da, Junior (2021). Learning sustainability in the harvesting practices of a forest-based company. Revista de Administração Mackenzie, 22 (5), 1-24. doi:10.1590/1678-6971/eRAMG210198

Submission: Apr. 22, 2020. Acceptance: Nov. 27, 2020.

\footnotetext{
${ }^{1}$ The second author is supported by the Brazilian National Council for Scientific and Technological Development (Conselho Nacional de Desenvolvimento Científico e Tecnológico - CNPq), under Grant no. 311291/2020-1, and the Foundation for Research and Innovation Support in Espírito Santo (Fundação de Amparo à Pesquisa e Inovação do Espírito Santo - Fapes), under Grant no. 229/2019.

${ }^{2}$ Federal University of Espírito Santo (Ufes), Vitória, ES, Brazil.
}

\section{(c) $\mathrm{BY}$}

\footnotetext{
This paper may be copied, distributed, displayed, transmitted or adapted for any purpose, even commercially, if provided, in a clear and explicit way, the name of the journal, the edition, the year and the pages on which the paper was originally published, but not suggesting that RAM endorses paper reuse. This licensing term should be made explicit in cases of reuse or distribution to third parties.

Este artigo pode ser copiado, distribuído, exibido, transmitido ou adaptado para qualquer fim, mesmo que comercial, desde que citados, de forma clara e explícita, o nome da revista, a edição, o ano e as páginas nas quais o artigo foi publicado originalmente, mas sem sugerir que a RAM endosse a reutilização do artigo. Esse termo de licenciamento deve ser explicitado para os casos de reutilização ou distribuição para terceiros.
} 


\section{ABSTRACT}

Purpose: The objective of this study is to understand how the learning process of sustainability occurs within the context of the harvesting practices of a forest-based company.

Originality/value: The study contributes to understanding the learning process of sustainability under the approach of practice when demonstrating how the knowledge of sustainability is created and reproduced from the practices established by a group. In practical terms, the narrative of the flow of knowing and learning has the potential of assisting managers and educators to structure more integrative corporate education projects, in which the initiatives are integrated into the practices of the occupational communities.

Design/methodology/approach: This is a qualitative research of descriptive nature, through a single-case study in a forest harvesting operation in a Brazilian company that has sustainability at the core of its business strategy. It was adopted as collection instruments the in-depth observation, the semi-structured interview, and the documental research, which were analyzed through the thematic analysis of narratives.

Findings: The results suggest that, in the given context, the learning process of sustainability happens in a combination of the processes of creation and dissemination of knowledge conducted by the company and the practices developed within the occupational communities. There are indications that, in a social construction process, new working models are learned, based on an entanglement of planning, safety, and discursive practices, activating the knowledge-in-practice of sustainability.

\section{KEYWORDS}

Learning process for sustainability. Knowledge-in-practice. Situated learning process. Practice-based studies. Sustainability. 


\section{INTRODUCTION}

The conceptual disagreements over the notion of sustainability, its real motives, and its inclusion in the daily practices of the organizations are widely discussed. The lack of conceptual agreement caused many concepts to be proposed, together with the proliferation of criticisms about the definition of goals and the coherence of the strategies to reach a sustainable development. Those debates can be justified as a result of the diversity expected during the emerging stage of any concept (Gladwin, Kenelly, \& Krause, 1995). Despite the lack of consensus and the criticisms, there are convergences regarding the important nature of the socio-environmental crisis in the world and the changes that are necessary (Ciegis, Ramanauskiene, \& Martinkus, 2009).

The debates about the necessity of turning sustainability into something operational are increasing, mitigating the gaps between the discourse and managerial practices (Waas et al., 2014). Le Roux and Pretorius (2016) argue that, as it is a fundamental theme for businesses, the speech of the organizations has been evolving, from an early stage regarding the doubt of its incorporation, going through the preoccupation of how to integrate it and being increasingly in search for how they can do better. However, even though there is the evolution of the speech, the authors argue that the concept is not reflected in the beliefs, practices, and decision-making of the organizational practitioners because of the implementation gap that imposes challenges.

Engert and Baumgartner (2016) claim that the absence of empirical studies about the implementation of corporate sustainability that help to reveal how companies can balance economic, environmental, and social needs, translating strategy into action, contributes to a slower transition. Among the gaps, the dyad education and learning has been considered as a key to sustainability (Benn \& Martin, 2010; Edwards, 2009; Henry, 2009; Le Roux \& Pretorius, 2016; Moyer \& Sinclair, 2020; Sidiropoulos, 2014; Organização das Nações Unidas para Educação, Ciência e Cultura, 2005; Wals, 2011; Wals \& Benavot, 2017).

Research on education and learning process for sustainability have been carried out and, although it is identified an increase in studies that consider the learning process for sustainability as a social process (D'Angelo \& Brunstein, 2014; Edwards, 2009; Figueiró, Bittencourt, \& Scuttel, 2016; Henry, 2009; Lankester, 2013; Madsen, 2013; Mello \& Godoy, 2014; Wals, 
2011), it still prevails the approaches that consider it as a process related to change capability and as a mechanism of organizational adaptation to the sustainability environment from individual learning (Wals \& Benavot, 2017).

Given the challenges that sustainability brings to society, such as the conflicts inherent to the choices made and the integration concept associated with the matters related to values, ethical behavior, amongst others, thinking of the learning process just as a cognitive perspective means to narrow the existing discussion. We argue, thus, about the need for broadening the understanding of learning for sustainability under a perspective of a participation and interaction process, connected with practices developed by a group (Bispo, 2013; Gherardi, Nicolini, \& Odella, 1998; Nicolini, Gherardi, \& Yanow, 2003).

In this study, the learning process is understood as a situated practice (Bispo, 2013; Gherardi et al., 1998; Nicolini et al., 2003); and sustainability is understood as a concept that embraces the need for balancing the economic, environmental, and social pillars associated to the long term perspective and the responsibility to future generations (Ciegis et al., 2009). We also recognize sustainability as something that is reflected in the practices of the organizational actors (Silva \& Figueiredo, 2017, 2020). Based on this understanding, we formulated the following research question:

- How does the learning process for sustainability happens in the context of the harvesting operations of a forest-based company?

Thus, aiming to understand how the learning process for sustainability occurs, we conducted qualitative research, through a single case study, within the context of the harvesting operations of a forest-based company that has sustainability at the core of its business strategy. The supporting arguments for the completion of this research rely on the possibility of 1 . broadening the understanding of sustainability as a concept that is reflected in a set of practices that are created, reproduced, and assumed by its actors (Silva \& Figueiredo, 2017, 2020); 2. contributing for the studies about the sustainability learning process as a social process; and 3. contributing for the structuration of sustainability-oriented corporate education projects which are more integrative, in which the initiatives may be connected and integrated to existing practices in the occupational communities' sphere.

The article is structured in four parts, besides this introduction. In the first one, it is presented the theoretical framework; in the second one, the methodological aspects; in sequence, the presentation and analysis of the data; and, finally, the final considerations. 


\section{THEORETICAL PATHWAY}

\subsection{The inclusion of sustainability in organizational environments}

The appropriation of natural resources and its arbitrary usage are part of an anthropocentric perspective that exists in the traditional management paradigm, which allows and justifies a way of exploration of the natural environment without taking into account the interdependency with the environment and the risks that arise from this way of production (Gladwin et al., 1995; Shrivastava, 1995). Based on this paradigm, organizations have created wealth through technological and scientific developments, disregarding the environment's biophysical limits (Ciegis et al., 2009) and social transformations.

Given the signs of the collapse of the 20th-century economic models and the increasing frequency of crises in different sectors, the movements for seeking more balanced models got stronger. These movements force the understanding of the circularity of processes and systems, the finitude of resources and its regenerative and inclusive nature, the recognition that a business environment involves the planet's ecology, the economic and social worlds, the political order, the market, the technology and the sociopolitical context of the organizations (Penteado, 2003; Vasconcelos, Silva, \& Silva, 2013), as well as the recognition of risks as a reflex of human actions and oversights (Shrivastava, 1995).

Although it is a recurrent agenda in the debates, this perspective still lacks a conceptual deepening and effective practices (Silva \& Figueiredo, 2017), which demands from all the parts involved a transdisciplinary perspective (Martens, 2006; Shrivastava, Ivanaj, \& Persson, 2013). It also demands a willingness to face changes in the way of acting, involving a revision of management practices and organizational strategy (Gladwin et al., 1995; Le Roux \& Pretorius, 2016; Müller \& Pfleger, 2014).

The inexistence of conceptual agreements and their inaccuracy (Mebratu, 1998; Sartori, Latronico, \& Campos, 2014), as well as the lack of coherence in the strategies to reach a sustainable development model, are pointed out as possible factors that interfere in the operational levels of sustainability (Ciegis et al., 2009; Munck, 2015; Müller \& Pfleger, 2014; Sartori et al., 2014). Despite the conceptual diversity, convergences are observed regarding: 1. the preoccupation of passing onto future generations the capital stock; 
2. the emphasis on collective values; 3 . the consequences of choices; and 4. the practice of collective ethics instead of an individual one (Sartori et al., 2014).

The challenges of including sustainability in the daily practice of the organizations also go through the multifaceted and complex nature of sustainability itself, turning into rules, no exceptions, the trade-offs, and conflicts in organizational environments. That is because the model that considers the interdependency between ecology, economy, and society brings up tensions to the organizations for presenting the juxtaposition and not approaching the systematic relationship between those dimensions (Gladwin et al.,1995; Hann, Pinkse, Preuss, \& Figge, 2015; Le Roux \& Pretorius, 2016; Müller \& Pfleger, 2014; Munck, 2015). Moreover, the predominant economic and/ or environmental perspective appears to be insufficient for sustainability to be understood and practiced among all the levels of the organization.

A model based on the sustaincentric paradigm has been discussed as an alternative to reconcile the different dimensions, where inclusion, connectivity, equity, prudence, and safety are expressed (Gladwin et al., 1995). This integrative approach considers different time scales of the social, environmental, and economic areas, prioritizing the long term (Munck, 2015), and it demands from the organizational actors cognitive and values transformation (Sidiropoulos, 2014; Vucetich \& Nelson, 2010), as well as the adoption of appropriate, fair and humane technologies by the organizations.

We understand that the introduction of this paradigm shifts the understanding of sustainability as a normative and homogeneous concept (Gladwin et al., 1995), represented by a set of sustainable technologies as well as by structures and rules existing in the organization, into something that is reflected in the practices of the organizational actors (Silva \& Figueiredo, $2017,2020)$. Therefore, we comprehend sustainability in this study as a multidimensional and dynamic concept (Müller \& Pfleger, 2014) that approaches the need for balance between the economic, environmental and social pillars, linked to the long term perspective and to the responsibility to future generations (Ciegis et al., 2009) and that it is embedded in the routine of the organizations as a set of practices that are created, reproduced and assumed by their actors (Silva \& Figueiredo, 2017, 2020).

\subsection{The learning process for sustainability and the knowledge- in-practice}

The studies on the organizational learning process show an increasing development in the past decades, being considered as a multidisciplinary 
and multiparadigmatic field (Antonello \& Godoy, 2010). Researches gravitate around the technical and social perspectives, and, through these lenses, one seeks to understand what and how individuals learn.

The starting point of the sociologic perspective is the experience lived in daily life and the learning process as part of taking part in the social life and the practice (Gherardi \& Nicolini, 2001; Gherardi, 2001, 2011), being necessary to analyze the context as a historical product built within the relationship among people. This approach disconnects from the perspective of learning by cognition and the search for information processing, as it conceives the learning process as a process of participation and interaction, being connected with a practice which is developed by a group (Bispo, 2013; Gherardi et al., 1998; Nicolini et al., 2003).

Analyzing knowledge within a situated practice implicates understanding that the learning process is a composition of knowing and doing (Bispo, 2013; Gherardi, 2001, 2009), and it is in the practice that the knowledge is manifested (Nicolini, 2011). When establishing connections between practice and knowledge, Gherardi (2014) indicates three types of non-exclusive relationships: 1. restraint relationship; 2. mutual constitution relationship; and 3. equivalence relationship.

In the restraint relationship, the author argues that knowledge has a place within the practices, and these, in their turn, are recognized by the practitioners. In those practices, there are "pieces of knowledge which are anchored on the material world that has been formed from the normative, cultural and aesthetic existing system" (Gherardi, 2014, p. 6). On the other hand, in the mutual constitution relationship, knowing and practicing are two phenomena that interact and produce one another, without having any distinction between them. Finally, in the equivalence relationship that, for being inseparable, one understands that "practicing is learning in practicing, whether the subject is aware of it, or not" (Gherardi, 2014, p. 7). Therefore, it is through the working practices that knowledge becomes observable and is produced and reproduced (Gherardi, 2009, 2014).

Several approaches have influenced the understanding of the organizational learning process in the practice-based perspective and, although they have different ontologies and epistemologies, they share the notion that knowledge is something practical and context-based (Nicolini et al., 2003). Likewise, the practice-based approaches do not arise from the same theory and, although they have similarities, they also have different terminology, history, assumptions, and traditions (Nicolini, 2011).

In this research, we understand the learning process as a situated practice (Bispo, 2013; Gherardi et al., 1998; Nicolini et al., 2003). In turn, the 
practice is comprehended as a "relatively time-stable and socially recognized method for arranging heterogeneous elements into a coherent set" (Gherardi, 2006, p. 34). That is, a practice is something that gives meaning and identity to a group (Nicolini, 2011) and which is organized from it; besides it, it is in the relationship between knowing and doing that the learning process is established in an unbreakable relationship between practice and learning process (Vogt, Bulgacov, \& Machado, 2020).

Studies that consider the learning process for sustainability as a social process are even more frequent, and they approach the networks, the collaborative work, and the practices created and negotiated as fomenters of the learning process, as they confer meanings (D'Angelo \& Brunstein, 2014; Edwards, 2009; Figueiró et al., 2016; Henry, 2009; Lankester, 2013; Madsen, 2013; Mello \& Godoy, 2014; Wals, 2011). Under the denomination of transdisciplinary learning process, transformative learning process, anticipated learning process, collaborative learning process, and social learning process, it is identified approaches that share the facts of: 1 . considering the learning process as something that goes beyond that one solely based on knowledge; 2. focusing on existentially relevant questions or "real", which involve the individuals; 3 . understanding the learning process as inevitably transdisciplinary and trans perspective; and 4. considering the indetermination as a key characteristic in the learning process (Wals, 2011).

However, although the learning process for sustainability fills an essential role for the development of sustainable behavior (Moyer \& Sinclair, 2020) and it has been noticed an increasing rise of the social approach, there is still the predominance of an instrumental and cognitive perspective of the learning process, associated with an individual changing process (Moyer \& Sinclair, 2020; Wals \& Benavot, 2017). This scenario indicates the hegemony of the psychological perspective and the managerial science of learning in organizations (Bispo \& Mello, 2012).

Thus, we argue that conceiving the learning process for sustainability in a cognitive, individual, and instrumental perspective is contradictory, as the reasons that bring the learning process to the main focus of sustainability discusses exactly the necessity of a process in which collaboration, sharing, shared meaning and synergy with multiple actors must be contemplated. The main point is that there is no unique model of education and learning for sustainability, although it is recognized the necessity that it is actionoriented, in a collaborative, participative, and transformative way (Wals \& Benavot, 2017). 


\section{METHODOLOGICAL PATHWAY}

In order to reach the aim of this study, we conducted a qualitative research of descriptive nature through a single case study (Flick, 2004; Stake, 2016). The research was carried out in one of the harvesting operations (SUL01 Harvest) of the Flora company, a fictitious name used to preserve the identity of the subjects involved. The company was created in 2009 as a result of the merge of two Brazilian companies: company A, founded in 1967, and company B, founded in 1988.

This research has a significant potential of comprehension of the theme in question because it is focused on the practical matters of the forest harvesting operation SUL01 of an organization that has sustainability in the core of its business strategy, being considered as a fundamental requirement for the growth and the creation of value for the businesses. Moreover, when approaching this operation, we broaden the possibility of understanding the learning process of these organizational actors from the observed practices and their narratives. In order to do so, we used in-depth observation, semistructured interviews, and documental research as collection instruments.

The in-depth observation was carried out in forest harvesting areas of three cities in the Southeast region of Brazil, watching the operations of cutting plan, felling, debarking, and preparation of the wood for transportation. During the observation period, several videos and pictures were taken, as well as notes, all of them registered in the field notebook (FN). Besides, we took part in technical and safety training, as well as in technical and managerial meetings within the period from August 2017 to January 2018, totalizing 80 hours of observation.

During the observation period, we conducted 15 semi-structured interviews with operators (EOp1, EOp2, EOp3), technicians (ET1 and ET2), coordinators (EC1, EC2, EC3, EC4, EC5, EC6), and managers (EG1, EG2, EG3, and EG4), aiming at broadening the understanding of what was being observed. The interviews were recorded and transcribed with the authorization of the interviewees. Finally, the documents selected for analysis were the forest harvest manual (D1), the training procedure (D2), the operator's training matrix (D3), and the operational, technical diagnosis (D4).

The data were analyzed using thematic analysis of narratives (Riessman, 2008), as it is a method applied to several stories that are developed within conversations, interviews, and written documents, seeking for the content that the narrative communicates and the similar thematic meanings among 
them. In thematic analysis, the focus is concentrated on the narrative's content and what we seek in the text is what is said and experienced by the narrator. Based on Riessman's (2008) premises, all the interviews were transcribed and read, isolating and categorizing episodes in chronological order. In addition, we analyzed the records of the FN and the documents trying to identify the themes defined a priori: 1 . flow of sustainability knowledge; and 2. practices established in the investigated context. Afterward, based on the observations and narratives, work safety, planning, and discursive were identified and discussed.

We present in the next section the characterization of the case study, the narrative of the sustainability learning process in this context, and the discussion about the sustainability learning process and the knowledge-inpractice.

\section{PRESENTATION AND ANALYSIS OF DATA}

\subsection{Research context}

The operation of forest harvesting involves the cutting and the preparation of the wood for transportation to supply cellulose factories, and it is characterized by the set of activities for the production of short and long wooden logs, with or without bark. It is performed using tools that cut, tear down, remove the branches, debark and outline the eucalyptus and remove all the wooden logs from the crop, taking them to the side of the roads, making piles to be transported later (FN). The cutting of the forest is carried out based on a plan made by specialized teams, and it obeys internal regulations for the operation, described in their own manual and monitored by an indicator system (D1).

The SUL01 Harvest operation, locus of the research, is located in the Southeast Region of Brazil, and it works in a 24 hour-system in three relay shifts. It is composed of a team of two operational technicians and 49 forest operators and one outsourced crew of approximately 38 professionals from three different outsourcing companies in the areas of maintenance and supply. The internal team consists of $100 \%$ male professionals, whose average company time is 16 years, all of them originally from company A. The follow-up and guidance routines are done by the operational technician because the management structure (supervisors and managers) remains in the administrative areas. 
The operational module, which works as an administrative basis and interaction space, is mobile and set up next to the cutting areas of the own company or outsourced. Those areas are temporary, and they change according to the cutting plan. The observations were made in 3 different cities, monitoring the same operational team.

\subsection{The narrative of sustainability learning process in forest harvesting practices}

A typical day in a harvesting operation starts with the commuting of the professionals in a rented bus headed to an operational area. At the disembarkation, they are taken to the module for their first meal, the daily safety meeting, the workplace exercise, and then they are distributed to their working areas until they get together again for the second meal or at the end of the shift (FN).

During the shift, by operating harvesting or transportation machines, these professionals aim at "producing piled up clean wood, with safety, quality and low cost" (EC1). In order to accomplish this goal, the operators rely on the operation manual, described by EC4 as the "operation compass", which establishes the standards for performing the harvest, following technical, environmental, quality, work safety, health, and hygiene criteria (D1) and the cutting plan available for each machine.

In order to ensure that the forest management practices reflect the productivity parameters, low cost, environmental and social responsibility, the organization provides, in a structured manner, a body of knowledge, such as training (D2, D3, D4), regulatory procedures (D1), indicators dashboard and monitoring routines. In the fieldwork (FN), we identified the organizational efforts to disseminate a shared sense of sustainable forest management practices. However, although it can be inferred from the narratives that those mechanisms work as a condition for sharing this common sense, in EC2's point of view, "sustainability that reaches the operational levels is equalized, but it is not resolved".

Despite the perception of EC2 that sustainability is not resolved, what we observed was that through the working practices, this group has been knowing/ practicing/ learning about sustainable forest management when producing and reproducing practices of anticipation and responsibility to the future, systemic perspective, self-care and care for the other and the responsibility in the decision-making in an integrative way (FN). That is, in activities based on practices, in the process of social construction, new ways 
of working sustained by an entanglement of practices have been learned. Among the several practices observed in this operation, three of them will be highlighted: 1 . planning practices, 2 . work safety practices and, 3. discursive practices. The choice was made because of the intensity with which they were experienced during the period in the field, both by observation and/or numerous narratives (FN).

The planning practices have been allowing this group to practice new ways of working through a collective ability that organizes and defines action limitations, establishes the ways of doing, that reframes short, medium, and long term perspectives, the perspective of the whole, the responsibility and sustainability. Whether it is in annual planning, microplanning, or in each operator's daily planning practices, what we noticed was that in the context of SUL01, Harvest, there is collective participation around a situated practice of planning, combining organizational procedures with this group's way of doing it (FN).

We observed meetings that aimed at elaborating the annual cutting plan, as well as two rounds of micro-planning. In the annual planning, the goal is to map the harvesting flow based on the guidelines of the organization; in the micro-planning, the goal is to monitor possible socioenvironmental impacts that will occur before and after each operation. When observing both practices, as well as the different interactions, we identified an intense negotiation process, with wide participation and producing order, which created a common understanding of what, how, and why doing so (FN).

For the EOP1, differently from the past, nowadays they operate with the "concern of not running over the stump, in order not to harm the sprouts that will grow". This concern is necessary because for ET1, "if we don't do it right, we don't go through it again". The "going through", in the language of the group, represents the return of the operation to the same community, in intervals from five to seven years, when a new harvesting cycle begins.

The broad participation observed is reported as an advance by EG2, when he says that "Before, only a few had the right to think. Nowadays, there are many more people thinking and assessing it". ET1 also affirms that, through planning, "we have learned to look ahead and not to increase the rhythm". Such narratives predominated, indicating that the planning practices change the work in the SUL01 Harvest operation. For ET1, "nowadays' operators think and plan. Unlike the past, where they didn't think or planned and killed themselves".

In this report, as well as in others, the professionals talk about the importance of planning for their activities and for learning a new way of 
acting (FN). This "new way of acting" means producing while regarding the pillars of productivity, safety, and quality. According to the operators, when those were not considered in the past, accidents happened, as well as illnesses, environmental and social problems that impacted the community.

During the observation of a microplanning in one of the operational areas, the talks revolved around the quality of the crop, quality of the roads, operation risks, deployment of the operational module, place to pile up the wood, machinery route, deadlines for the outsourcing company to finish their activities, and other factors. During the path between farms, we heard reports on the harvesting supervisors' initial rejection of this process for not making decisions by themselves anymore. In addition, they pointed out the gains to the communities by avoiding many current problems and to the fact that the practice works as a database to store information on the area (FN).

Besides the practices that materialize the long-term perspective and the systemic view, which are exercised through the planning, we identified that, in the work routine of this group, they have been producing a situational perspective of respect, personal safety, and of others and respect for life. It has been through these practices of safe work that these professionals have been producing and reproducing this knowledge based on values of care and responsibility among them. In EG2's point of view, safety "changed the relationships in operation, growing from a strong sense of responsibility that has been developed".

Despite the isolated work in their machines, the operators use the radio communication system to practice safety actions, such as alerting others about risks in operation, animal presence, to ask for help in risky operations and, during our observations, what we saw was a group sharing of experiences and producing meanings about danger, safety, and caution and the respective behaviors that should have been adopted at that moment. We witnessed the use of reports, conversations about safety during face-toface meetings at the beginning and ending of shifts, records on shift notebooks with the safety incidents, preliminary analysis of any task, among other practices.

In the narratives, safety was pointed out as one of the ways of understanding sustainability, for both concepts are related to survival. Moreover, the perspective that safety is something that is learned by practicing is shared by several members of this occupational community. In one of the interactions during the observation, EOP3, who was new in the operation, highlighted how the experienced ones have helped him understand the value of safety, health, and taking care of the environment since his introduction to the group's practices. 
We also observed that the safety practices had given this community identity, from the development of the collective meaning of what it means to be safe and the understanding of what it is to operate in a sustainable way. During the research, this group had been working for 43 months without any working accidents, becoming a reference to the whole company that, even though they kept the same procedures to all the units, there was no other forest and/ or industrial operation maintaining the same indicator.

Both planning and safety practices are mediated by language, and distinct discursive practices were identified, such as different planning results evaluation meetings, stay alert and secure frequency, the operational book which is produced by the team that leads the microplanning and then makes it available to be consulted as a way of recording everything that was negotiated between the ones involved, conversations about the environment and safety, meetings at the beginning of shifts, among others. Both in the reports and in the observations and documents, it is possible to identify other practices in which language organizes the practice and grants participation.

In the meetings, we noticed intense participation, and this behavior, according to the operators, is part of the change in the communication flow and the increase in the level of formal education. This behavioral change is mentioned by many of them as a transition from the role of "wood carrier to owner of the process" operator (ET1). This expression was heard several times during the research, and it was used to demonstrate the greater level of participation of the professionals in the process.

Finally, based on everything that we collected, we argue that, in the context of SUL01 Harvest, from planning, work safety, and discursive practices, it has been possible for this group to practice and learn premises contained in the ideal of sustainability, through the interactions among the organizational practitioners and in a situated manner, which we will discuss from now on.

\subsection{The discussion about the sustainability learning process and knowledge-in-practice}

The learning process has been pointed out as one of the key themes for the operationalization of sustainability, for it allows the development of sustainable behavior (Moyer \& Sinclair, 2020). However, it is still noticed the predominance of studies with an instrumental and cognitive perspective of the learning process associated with an individual changing process (Moyer \& Sinclair, 2020; Wals \& Benavot, 2017). 
When choosing the situated learning process approach, we try to contribute with the understandings that sustainability is a concept with different dimensions, which is not assimilated by everyone the same way, but rather understood and appropriated, as it is introduced in the routine of the organizations as a set of practices that are created, reproduced and appropriated by their actors (Silva \& Figueiredo, 2017, 2020). This is so because, despite the transformation of organizational elements (Engert \& Baumgartner, 2016), it is necessary that the individuals' present values, knowledge, and practices that are different from the traditional management model, as discussed by Gladwin et al. (1995) and Le Roux and Pretorius (2016).

We noticed that, although the institutional mechanisms of Flora company are structured to make available a body of knowledge about sustainability, in the context of the SUL01 Harvest, the knowledge of sustainability is an activity located in the participation (Gherardi \& Nicolini, 2001; Gherardi, 2001, 2011). That is, through the practices that produce order and meaning to the routine, this group has been experiencing in their daily tasks key elements of sustainability, such as inclusion, connectivity, prudence, and safety (Gladwin et al., 1995), as well as the long term perspective and carefulness with the operator himself and the others. Nonetheless, differently from an instrumental and cognitive perspective associated with an individual changing process, still so present in the learning process models for sustainability (Moyer \& Sinclair, 2020; Wals \& Benavot, 2017), in this context, the knowledge about sustainability has been activated in the practices, where knowing and doing are entangled (Bispo, 2013; Gherardi, 2001, 2009; Nicolini, 2011).

When approaching the working practices of this occupational community, we identified that, in working together in the creation and maintenance of the negotiated practices in the routine, these professionals have been concentrating on what matters to them, based on the understanding of what it is to be sustainable. In the process of social construction and in the entanglement of practices, more specifically in the planning, work safety, and discursive practices, this group has been experiencing, in their daily tasks, key elements of sustainability that are incorporated into their working routines and decision-making processes.

It is through those practices, in a relationship of containment, mutual constitution, and equivalence, that the knowledge becomes observable and it is produced and reproduced (Gherardi, 2009, 2014), activating the practice knowledge of systemic view, of carefulness, of responsibility, of an integrative perspective and of a look to the future. In this context, sustainability is enabled with the search for the balance of the dimensions, through the 
activation of diverse knowledge produced by this community, without being necessary the complete individual mastery, creating an interdependency within the actions which are reflected in the decision making. It is important to highlight that the interpretation of what are tripartite results of business is one of the operationalization gaps discussed by Waas et al. (2014), and the way in which the professionals confer meaning to those dimensions may indicate that, in this context, there is already an understanding from the practices established by the group.

Another aspect to be emphasized is related to the work safety practices observed. In the workplace safety practice, this community develops a collective meaning of what it is to be safe and sustainable. This collective understanding enables decision-making processes based on negotiation, causing changes in the practices, aiming at the preservation of life, the environment, and production. That is, in this context, there are signs that safety is an emergent competence that is performed in practice, that is socially built and communicated to the new members of this community, and that is embedded in values, norms, and social institutions (Gherardi, 2018). Besides, it also evinces what is discussed by Gherardi and Nicolini (2002) about not learning safety but work safety practices.

The narratives of the new operators about what they had to learn to be considered experienced operators indicate the existence of a situated curriculum, which has a tacit nature and expresses the ongoing working practices and the social interactions (Gherardi et al.,1998). The analysis allows us to infer that, given the nature of the activity, this situated curriculum and the learning curriculum proposed by the company, based on procedures related to machine operation, administrative routines, and safety manuals, are complementary, and this is what ensures that a new operator can be considered experienced in operation.

Therefore, we can argue that our observations corroborate what is discussed by Gherardi $(2006,2014)$ about the situated nature of the learning process and the characteristics of the relational knowledge and the learning process based on ways of involvement and participative appropriation, creating associations between mental and material elements and producing a body of knowledge shared by the involved communities. Language is the key instrument of this measurement and, through the discursive practices, this group has been establishing alliances, building common concepts, producing and reproducing practices that change the way of doing and knowing.

All those practices seem to indicate a recurring narrative that, in this working context, there has been a change in the communication flow, in the 
volume and in the quality of information, with the increase of the participation of the people and that all that allows the group to organize itself around the "knowing how we go" (Gherardi, 2018). The larger participation of these operators suggests a disruption of a mechanistic logic that predominated in this organization, in which the operator was not a thinking being but rather a labor force whose most privileged characteristic was the physical strength and the repetition capacity.

Nonetheless, as it is also discussed by Wals (2011), it is through the dialogue that objectives of co-ownership and shared meanings can favor the construction of a future desired by all the parts involved and, different from the past (where sustainability was the responsibility of those with the most authority and influence), from the practice of knowledge and the knowledge-in-practice, this increases the possibility of appropriation of the concept and changes in the actions. Therefore, facing the necessity of establishing business models in which are considered the economic, environmental, and social pillars in an integrated way and that contain a longterm perspective and the responsibility to future generations, and, being the learning process considered a fundamental piece of this change, we deem necessary to shift the understanding of the learning process for sustainability as a mere cognitive process to a process of participation and interaction.

The process of learning is, therefore, associated with a practice developed by a group that, on a daily basis, negotiates, shares meanings, and establishes new actions and knowledge, evidencing the indissolubility between practice and the learning process (Vogt et al., 2020). We also argue that those practices are anchored in normative knowledge and in a cultural system, not having a dualism between what is learned through the routines of the company and what is produced in the communities; on the contrary, there is an association of both practices, in a movement in which all the elements contribute to this process.

\section{FINAL CONSIDERATIONS}

In order to understand how the learning process for sustainability occurs in a forest operation, we conducted a qualitative research at the SUL01 Harvest operation, which belongs to a Brazilian company that has sustainability at the core of its business strategy. In this study, the learning process is understood as a situated practice (Bispo, 2013; Gherardi et al., 1998; Nicolini et al., 2003), and sustainability is understood as a multidimensional concept associated with long term perspective and responsibility to 
future generations (Ciegis et al., 2009) and which reflects in the practices of the organizational actors (Silva \& Figueiredo, 2017, 2020). Guided by the objective and the theoretical frame, we built the data from in-depth observation, semi-structured interviews, and documental research. The data were analyzed through thematic analysis of narratives (Riessman, 2008).

We identified that institutional mechanisms of Flora company, such as training and normative procedures, guide the expected social, environmental, and economic parameters of a sustainable forest operation. However, it has been through the entanglement of practices of this occupational community and, more specifically, of planning, safety, and discursive practices, that these practitioners have been activating knowledge about the fundamental elements of sustainability, incorporating them into their working routines and decision-making processes. In the daily operation, the knowledge-in-practice of systemic perspective, carefulness, responsibility, integrative view, and look to the future have been practiced and, in a collective construction, which grants meaning and identity, this group has been producing and reproducing practices that enable the learning process of sustainability.

We recognize the limitations of the study, as, for example, the fact of having concentrated the research at the context of the SUL01 Harvest and the fact of not doing it in a continuous way, restricting the understanding of the process of doing and learning sustainability. However, despite the limitations pointed out here and already encouraging new research to amplify this debate, we understand that, still, the research brings contributions.

When arguing that the learning process in the context of sustainability implies the situated knowledge, we seek to contribute to a more integrative perspective of the learning process and to broaden research that tries to identify new frames and new practices in the organizational contexts, considering that there is not only one model or learning process for sustainability (Wals \& Benavot, 2017). In the theoretical perspective, the study contributes to the maturation of the learning process for the sustainability theme and to discussions about the understanding of sustainability as a set of practices and a situated concept. In turn, regarding practical implications, we hope that the flow of the knowing and learning identified here may serve as a reference so that managers and corporate educators structure corporate educational projects which are more integrative and that the organizational initiatives are integrated into the occupational communities' practices.

We hope that these contributions assist in the search for alternatives to the learning process for sustainability, considering the importance of the theme in view of the existing discrepancies and of the complexity of current challenges. 


\section{O APRENDER SUSTENTABILIDADE NAS PRÁTICAS DE COLHEITA DE UMA EMPRESA DE BASE FLORESTAL}

\section{RESUMO}

Objetivo: O objetivo deste estudo é compreender como a aprendizagem para a sustentabilidade acontece no contexto das práticas de colheita de uma empresa de base florestal.

Originalidade/valor: O texto contribui para a compreensão da aprendizagem para a sustentabilidade na perspectiva da prática ao evidenciar como o saber sobre sustentabilidade é criado e reproduzido a partir das práticas estabelecidas por um grupo. Em termos práticos, a narrativa do fluxo do conhecer e do aprender tem potencial para auxiliar gestores e educadores na estruturação de projetos de educação corporativa mais integradores, nos quais as iniciativas estejam integradas às práticas das comunidades ocupacionais.

Design/metodologia/abordagem: Trata-se de uma pesquisa qualitativa de caráter descritivo, por meio de estudo de caso único em uma operação de colheita florestal de uma empresa brasileira que tem a sustentabilidade no núcleo de sua estratégia de negócios. Como instrumentos de coleta, adotaram-se a observação direta, a entrevista semiestruturada e a pesquisa documental. Os dados foram analisados a partir da análise temática de narrativas.

Resultados: Os resultados indicam que, no contexto investigado, a aprendizagem da sustentabilidade se dá em uma conjugação dos processos de geração e disseminação de conhecimento conduzidos pela empresa e nas práticas desenvolvidas nas comunidades ocupacionais. Há indicativos de que, em um processo de construção social, novos modos de trabalho são aprendidos, sustentados por um entrelaçamento de práticas de planejamento, de segurança e discursivas, ativando o saber em prática da sustentabilidade.

\section{PALAVRAS-CHAVE}

Aprendizagem para a sustentabilidade. Saber na prática. Conhecimento situado. Estudos baseados na prática. Sustentabilidade. 


\section{REFERENCES}

Antonello, C. S., \& Godoy, A. S. (2010). A encruzilhada da aprendizagem organizacional: Uma visão multiparadigmática. Revista de Administração Contemporânea, 14(2), 310-332. doi:10.1590/S1415-65552010000200008

Benn, S., \& Martin, A. (2010). Learning and change for sustainability reconsidered: A role for boundary objects. Academy of Management Learning $\mathcal{E}$ Education, 9(3), 397-412. doi:10.5465/amle.9.3.zqr397

Bispo, M. S. (2013). Aprendizagem organizacional baseada no conceito de prática: Contribuições de Silvia Gherardi. Revista de Administração Mackenzie, 14(6), 132-161. doi:1590/S1678-69712013000600007

Bispo, M. S., \& Mello, A. S. (2012). A miopia da aprendizagem coletiva nas organizações: Existe uma lente para ela? Revista Gestão e Planejamento, 12(3), 728-745. Recuperado de https://revistas.unifacs.br/index.php/ $\mathrm{rgb} / \mathrm{article} / \mathrm{view} / 2252$

Ciegis, R., Ramanauskiene, J., \& Martinkus, B. (2009). The concept of sustainable development and its use for sustainability scenarios. Inzinerine Ekonomika-Engineering Economics, (2), 28-37. Recuperado de https://www. inzeko.ktu.lt/index.php/EE/article/view/11609

D’Angelo, M. J., \& Brunstein, J. (2014). Social learning for sustainability: Supporting sustainable business in Brazil regarding multiple social actors, relationships and interests. International Journal of Sustainable Development $\mathcal{E}$ World Ecology, 21 (3), 273-289. doi:10.1080/13504509.2014.902868

Edwards, M. G. (2009). An integrative metatheory for organisational learning and sustainability in turbulent times. The Learning Organization, 16(3), 189-207. doi:10.1108/09696470910949926

Engert, S., \& Baumgartner, R. J. (2016). Corporate sustainability strategy: Bridging the gap between formulation and implementation. Journal of Cleaner Production, 113, 822-834. doi:10.1016/j.jclepro.2015.11.094

Figueiró, P. S., Bittencourt, B. A., \& Schutel, S. (2016). Education for sustainability in business schools by practicing social learning. Brazilian Journal of Science and Technology, 3(1), 1-16. doi:10.1186/s40552-016-0014-7

Flick, U. (2004). Introdução à pesquisa qualitativa. Porto Alegre: Bookman.

Gherardi, S. (2001). From organizational learning to practice-based knowing. Human Relations, 54(1), 131-139. doi:10.1177/0018726701541016

Gherardi, S. (2006). Organizational knowledge: The texture of workplace learning. Oxford: Blackwell. 
Gherardi, S. (2009). Knowing and learning in practice-based studies: An introduction. The Learning Organization, 16(5), 352-359. doi:10.1108/096 96470910974144

Gherardi, S. (2011). Organizational learning: The sociology of practice. In M. Easterby-Smith \& M. A. Lyles (Eds.), Handbook of organizational learning \& knowledge management (2nd ed., pp. 43-65). West Sussex: Wiley.

Gherardi, S. (2014). Conhecimento situado e ação situada: O que os estudos baseados em prática prometem? In S. Gherardi \& A. Strati, Administração e aprendizagem na prática (pp. 3-17). Rio de Janeiro: Elsevier.

Gherardi, S. (2018). A practice-based approach to safety as an emergent competence. In C. Bieder, C. Gilbert, B. Journé, \& H. Laroche (Eds.), Beyond safety training: Embedding safety in professional skills (pp.11-21). Paris: Springer Open.

Gherardi, S., \& Nicolini, D. (2001). The sociological foundations of organizational learning. In M. Dierkes, A. Berthoin Antal, I. Nonaka, \& J. Child (Orgs.), Handbook of organizational learning and knowledge (pp. 35-60). Oxford: Oxford University Press.

Gherardi, S., \& Nicolini, D. (2002). Learning in a constellation of interconnected practices: Canon or dissonance? Journal of Management Studies, 39(4), 419-436. doi:10.1111/1467-6486.t01-1-00298

Gherardi, S., Nicolini, D., \& Odella, F. (1998). Toward a social understanding of how people learn in organizations the notion of situated curriculum. Management Learning, 29(3), 273-297. doi:10.1177\%2F1350507698293002

Gladwin, T. N., Kennelly, J. J., \& Krause, T. (1995). Shifting paradigms for sustainable development: Implications for management theory and research. Academy of Management Review, 20(4), 874-907. doi:10.5465/ amr.1995.9512280024

Hann, T, Pinkse, J., Preuss, L., \& Figge, F. (2015). Tensions in corporate sustainability: Towards an integrative framework. Journal of Business Ethics, 127(2), 297-316. doi:10.1007/s10551-014-2047-5

Henry, A. D. (2009). The challenge of learning for sustainability: A prolegomenon to theory. Human Ecology Review, 16 (2), 131-140. Recuperado de https://ajph.humanecologyreview.org/pastissues/her162/henry.pdf

Lankester, A. J. (2013). Conceptual and operational understanding of learning for sustainability: A case study of the beef industry in north-eastern Australia. Journal of Environmental Management, 119, 182-193. doi:10.1016/ j.jenvman.2013.02.002 
Le Roux, C., \& Pretorius, M. (2016). Navigating sustainability embeddedness in management decision-making. Sustainability, 8(5), 1-23. doi:10.3390/ su8050444

Madsen, K. D. (2013). Unfolding education for sustainable development as didactic thinking and practice. Sustainability, 5(9), 3771-3782. doi:10.33 90/su5093771

Martens, P. (2006). Sustainability: Science or fiction? Sustainability: Science, Practice, \& Policy, 2(1), 36-41. doi:10.1080/15487733.2006.11907976

Mebratu, D. (1998). Sustainability and sustainable development: Historical and conceptual review. Environmental Impact Assessment Review, 18(6), 493-520. doi:10.1016/S0195-9255(98)00019-5

Mello, A. S., \& Godoy, A. S. (2014). Integrando o conceito de aprendizagem social pelas perspectivas da sustentabilidade e da aprendizagem organizacional. In J. Brunstein, A. S. Godoy, \& H. C. Silva (Orgs.), Educação para sustentabilidade nas escolas de administração (pp. 28-54). São Carlos: Rima.

Moyer, J. M., \& Sinclair, A. J. (2020). Learning for sustainability: Considering pathways to transformation. Adult Education Quarterly, 70(4), 340-359. doi:10.1177/0741713620912219

Müller, A. L., \& Pfleger, R. (2014). Business transformation towards sustainability. Business Research, 7(2), 313-350. doi:10.1007/s40685-014-0011-y

Munck, L. (2015). Gestão da sustentabilidade em contexto organizacional: Integrando sensemaking, narrativas e processo decisório estratégico. Organizações E Sociedade, 22(75), 521-538. doi:10.1590/1984-9230753

Nicolini, D. (2011). Practice as the site of knowing: Insights from the field of telemedicine. Organization Science, 22(3), 602-620. doi:10.1287/orsc. 1100.0556

Nicolini, D., Gherardi, S., \& Yanow, D. (2003). Introduction: Towards a practice-based view of knowing and learning in organisations. In D. Nicolini, S. Gherardi, \& D. Yanow (Eds.), Knowing in organisations: A practice-based approach (pp. 3-31). London: M. E. Sharpe.

Organização das Nações Unidas para a Educação, a Ciência e a Cultura (2005). Década das Nações Unidas para o desenvolvimento sustentável, 2005-2014: Documento final do esquema internacional de implementação. Brasília: Unesco. Recuperado de https://unesdoc.unesco.org/ark:/48223/pf0000139937_por

Penteado, H. (2003). Ecoeconomia: Uma nova abordagem. São Paulo: Lazuli.

Riessman, C. K. (2008). Narrative methods for the human sciences. London: Sage. 
Sartori, S., Latronico, F., \& Campos, L. M. S. (2014). Sustentabilidade e desenvolvimento sustentável: Uma taxonomia no campo da literatura. Ambiente e Sociedade, 17(1), 1-22. doi:10.1590/S1414-753X2014000100002

Shrivastava, P. (1995). Ecocentric management for a risk society. Academy of Management Review, 20(1), 118-137.

Shrivastava, P., Ivanaj, S., \& Persson, S. (2013). Transdisciplinary study of sustainable enterprise. Business Strategy and the Environment, 22 (4), 230-244. doi:10.1002/bse.1773

Sidiropoulos, E. (2014). Education for sustainability in business education programs: A question of value. Journal of Cleaner Production, 85, 472-487. doi:10.1016/j.jclepro.2013.10.040

Silva, M. E., \& Figueiredo, M. D. (2017). Sustainability as practice: Reflections on the creation of an institutional logic. Sustainability, 9(10), 1-13. doi:10.3390/su9101839

Silva, M. E., \& Figueiredo, M. D. (2020). Practicing sustainability for responsible business in supply chains. Journal of Cleaner Production, 251, 119621. doi:10.1016/j.jclepro.2019.119621

Stake, R. (2016). Pesquisa qualitativa: Estudando como as coisas funcionam. Porto Alegre: Penso.

Vasconcelos, K. C. A., Silva, A., Junior, \& Silva, P. O. M. (2013). Educação gerencial para atuação em ambientes de negócios sustentáveis: Desafios e tendências de uma escola de negócios brasileira. Revista de Administração Mackenzie, 14(4), 45-75. doi:10.1590/S1678-69712013000400003

Vogt, S., Bulgacov, Y. L. M., \& Machado, R. C. (2020). "Quem sabe faz (ou já fez) ao vivo!": Um ensaio teórico sobre a indissolubilidade entre a prática e a aprendizagem. Revista Ciências Administrativas, 25 (4), 1-14. doi:10.5020/ 2318-0722.2020.8199

Vucetich, J. A., \& Nelson, M. P. (2010). Sustainability: Virtuous or vulgar? BioScience, 60(7), 539-544. doi:10.1525/bio.2010.60.7.9

Waas, T., Hugé, J., Block, T., Wright, T., Benitez-Capistros, F., \& Verbruggen, A. (2014). Sustainability assessment and indicators: Tools in a decisionmaking strategy for sustainable development. Sustainability, 6(9), 5512-5534. doi:10.3390/su6095512

Wals, A. E. J. (2011). Learning our way to sustainability. Journal of Education for Sustainable Development, 5(2), 177-186. doi:10.1177\%2F0973408211 00500208 


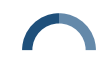

\section{Wals, A. E. J., \& Benavot, A. (2017). Can we meet the sustainability challenges? The role of education and lifelong learning. European Journal of Education, 52 (4), 404-413. doi:10.1111/ejed.12250}

\section{AUTHOR NOTES}

Kátia Cyrlene de Araujo Vasconcelos, Ph.D. from the Center for Legal and Economic Sciences (CCJE), Federal University of Espírito Santo (Ufes); Annor da Silva Junior, Ph.D. from the Faculty of Economic Sciences (Face), Federal University of Minas Gerais (UFMG).

Kátia Cyrlene de Araujo Vasconcelos is now a professor of higher education (federal public servant) at the CCJE-Ufes; Annor da Silva Junior is now a professor of higher education (federal public servant) at the CCJE-Ufes.

Correspondence concerning this article should be addressed to Kátia C. A. Vasconcelos, Avenida Fernando Ferrari, 514, campus Universitário Goiabeiras, Goiabeiras, Vitória, Espírito Santo, Brazil, CEP 29075-910.

E-mail: katiacavasconcelos@gmail.com; katia.vasconcelos@ufes.br

\section{EDITORIAL BOARD}

Editor-in-chief

Gilberto Perez

Associate editor

Simone Costa Nunes

Technical support

Vitória Batista Santos Silva

\section{EDITORIAL PRODUCTION}

Publishing coordination

Jéssica Dametta

Language editor

Daniel de Almeida Leão

Layout designer

Emap

Graphic designer

Libro 